\title{
PROMOSI DAN PEMETAAN MAHASISWA BARU PROGRAM STUDI (S1) TEKNIK SIPIL JURUSAN PENDIDIKAN TEKNIK BANGUNAN FAKULTAS TEKNIK UNIMED
}

\author{
Syafiatun Siregar ${ }^{1}$, Nahesson Panjaitan ${ }^{2}$ \\ 1,2Dosen Pengajar Jurusan Pendidikan Teknik Bangunan, Fakultas Teknik, UNIMED, Medan \\ Surel : syafiatunsiregar@gmail.com ${ }^{1}$,nahessonpanjaitan@gmail.com ${ }^{2}$
}

Diterima : 23 Maret 2018; Disetujui : 10 April 2018

\begin{abstract}
ABSTRAK
Program Studi S1 Teknik Sipil Unimed pada tahun ajaran semester Ganjil 2017/2018 menerima mahasiswa baru untuk pertama kalinya. Peranan sosialisasi dan promosi dilakukan agar program studi dapat dikenal luas oleh masyarakat Kota Medan khususnya dan umumnya propinsi Sumatera Utara serta secara regional di seluruh Nusantara dapat mengenal progam studi ini. Tujuan dari kegiatan adalah untuk mensosialisasikan keberadaan Program Studi, untuk mengenalkan dan mempromosikan program Studi di wilayah Kota Medan dan Kabupaten Kota sekitarnya dan untuk memetakan mahasiswa baru Program Studi S1 Teknik Sipil Unimed. Metode yang dilakukan dengan cara mengunjungi dan mempresentasikan materi sosialisasi dan promosi program studi Teknik Sipil di beberapa sekolah, menyebarkan informasi melalui brosur ke beberapa sekolah umum dan kejuruan yang berada di Sumatera Utara. Hasilnya adalah jumlah mahasiswa baru yang terdaftar pada program studi Teknik Sipil S1 berjumlah 86 orang dari jumlah peminat sebanyak 1431 orang dengan tingkat persaingan cukup tinggi yaitu $1: 28$. Daerah asal mahasiwa sudah secara regional mencakup pulau Sumatera dan Pulau Jawa. Informasi keberadaan Teknik Sipil S1 PTB FT Unimed diketahui melalui sekolah, Web, jejaring sosial, alumni dan lain-lain, Umumnya Program studi S1 Teknik Sipil merupakan pilihan pertama dari mahasiswa baru.
\end{abstract}

Kata Kunci : Program Studi S1 Teknik Sipil, Sosialisasi Dan Promosi, Unimed

\begin{abstract}
The Civil Engineering (S1) Study Program Unimed in the year of Odd semester 2017/2018 accepts new students for the first time. The role of socialization and promotion is done so that the study program can be widely known by the people of Medan City in particular and generally the province of North Sumatra and regionally throughout the archipelago can be familiar with this study program. The purpose of the activity is to socialize the existence of the Study Program, to introduce and promote the Study program in the area of Medan City and the surrounding Kota District and to map the new students of Unimed Civil Engineering S1 Program. The methods are undertaken by visiting and presenting the socialization materials and promotion of Civil Engineering courses in some schools, disseminate information by distributing flyers to public and vocational schools located in North Sumatra. The result is the number of new students enrolled in the Civil Engineering program (S1) amounted to 86 people from the number of applicants as many as 1431 people with a high level of competition is 1: 28. The origin of students already regionally covers the island of Sumatra and Java. Information on the existence of Civil Engineering (S1) PTB FT Unimed known through schools, Web, social networking, alumni, and others. Generally, Civil Engineering (S1) study program is the first choice of new students.
\end{abstract}

Keywords: Civil Engineering Study Program (S1), Socialization and Promotion, Unimed. 


\section{Syafiatun Siregar - Nahesson Panjaitan}

\section{Pendahuluan}

Perkembangan perguruan tinggi (PT) seperti universitas, sekolah tinggi, politeknik maupun akademi di Kota Medan sangat pesat terutama PT swasta. Sejumlah program studi yang bervariasi terdapat di dalam masingmasing perguruan tinggi. Universitas yang ada di Kota Medan umumnya memiliki multi jurusan/program studi. Secara garis besar setiap universitas tersebut mempunyai program studi teknik sipil yang berada dibawah naungan fakultas Teknik. Terdapat 4 Perguruan Tinggi Negeri (PTN) di Propinsi Sumatera Utara yaitu, Universitas Sumatera Utara, Universitas Negeri Medan, Universitas Islam Negeri Dan Politeknik Negeri Medan. Dari keempat PTN ini hanya UIN yang tidak memiliki Fakultas Teknik dan program studi teknik Sipil. Sedangkan hampir semua PT Swasta memiliki Fakultas teknik dan Program Studi Teknik Sipil.

Keberadaan Program Studi Teknik Sipil di Kota Medan pada masa sekarang ini, cukup diperhitungkan dalam dunia kerja, baik sebagai tenaga kependidikan maupun sebagai tenaga profesional keteknik sipilannya. Kurikulum inti masing-masing universitas yang digunakan telah menekankan keunggulan, kompetensi dan spesifikasi tertentu, sehingga dapat bersaing antara lulusan. Jurusan Pendidikan Teknik Bangunan Unimed saat ini cukup diperhitungkan baik oleh perguruan tinggi negeri maupun perguruan tinggi swasta yang sekarang ini telah mempunyai 3 (tiga) Program Studi yaitu Pendidikan Teknik Bangunan, Teknik Sipil D3 dan Teknik Sipil S1. Pasar kerja Teknik Sipil yang cukup luas menjadikan program studi teknik sipil adalah prioritas dalam pemilihan program studi ketika memasuki perguruan tinggi. Hal ini merupakan dasar pertimbangan atas suatu keberhasilan bahwa materi yang diberikan di bangku kuliah dapat menjawab dan mengisi berbagai jenis lapangan pekerjaan.

Program Studi Teknik Sipil masih menjadi pilihan yang banyak diminati oleh lulusan SLTA/Calon Mahasiswa di Kota Medan, sedangkan jumlah calon yang dapat ditampung di Perguruan Tinggi Negeri sangat sedikit, sebagian besar calon yang tidak tertampung akhirnya memilih Perguruan Tinggi Swasta yang biayanya relatif lebih mahal.

Program Studi Teknik Sipil pada Perguruan Tinggi Negeri khususnya di Kota Medan umumnya Propinsi Sumatera Utara saat ini hanya diakomodasi oleh satu Perguruan
Tinggi Negeri saja (USU, Unimed dan Politeknik), sedangkan peminat pada Prodi Teknik Sipil cukup banyak untuk level Propinsi dan kompetisi untuk masuk ke perguruan tinggi negeri tersebut sangat ketat. Oleh karena itu Universitas Negeri Medan pada tahun 2017 telah dapat menerima mahasiswa Prodi teknik Sipil untuk mengakomodirnya.

Program Studi Teknik Sipil Universitas Negeri Medan berdiri pada Tahun 2016, berdasarkan SK Keputusan Menteri Riset, Teknologi dan Pendidikan Tinggi Republik Indonesia Nomor 173/KPT/I/2016. Program studi Teknik Sipil S1 (Unimed) Jurusan Pendidikan Teknik Bangunan akan membuka Program Studi teknik Sipil (S1) yang dimulai pada Tahun Ajaran 2017/2018 dengan mengacu standard kurikulum KKNI (Kerangka Kualifikasi Nasional Indonesia).

Untuk mencari dan menumbuh minatkan mahasiswa memasuki program studi maka, perlu dilakukan suatu kegiatan promosi dan sosialisasi yang merupakan sarana yang strategis dalam mengenalkan program studi baru pada masyarakat dan dunia persekolahan terutama siswa kelas 12 di SMA/Sederajat di Sumatera Utara. Diharapkan dengan adanya kegiatan ini masyarakat pada umumnya, dan siswa kelas 12 khususnya di sekitar Sumatera Utara dapat mengetahui adanya program studi tersebut pada suatu universitas.

Kegiatan promosi dan sosialisasi pada tahun 2017 ini, diharapkan mampu memberikan gambaran yang lebih jelas dan sumber informasi yang lebih terbaru pada masyarakat Kota Medan khususnya, umumnya masyarakat propinsi Sumatera Utara, terutama siswa kelas 12 sekolah umum dan kejuruan dalam hal mengenal program studi Teknik Sipil (S1) di Universitas Negeri Medan (Unimed). Informasi yang disampaikan pada kegiatan promosi dan sosialisasi ini diharapkan meningkatkan minat/antusias siswa mendaftarkan diri pada ujian/ seleksi nasional SBMPTN dan SLMPTN tahun 2017 pada program studi Teknik Sipil, UNIMED.

Tujuan dari Penelitian ini adalah

a. Untuk mensosialisasikan keberadaan Program Studi S1 Teknik Sipil Fakultas Teknik Unimed sebagai salah satu prodi baru di jurusan Pendidikan Teknik Bangunan.

b. Mengenalkan dan mempromosikan program Studi di wilayah Kota Medan dan Kabupaten Kota sekitarnya 


\section{Promosi Dan Pemetaan Mahasiswa Baru Program Studi (S1) Teknik Sipil Jurusan Pendidikan Teknik Bangunan Fakultas Teknik Unimed}

c. Memetakan mahasiswa Program Studi S1 Teknik Sipil Unimed

\section{Kajian Pustaka}

\subsection{Pengertian Promosi}

Promosi adalah upaya untuk memberitahukan atau menawarkan produk atau jasa pada dengan tujuan menarik calon konsumen untuk membeli atau mengkonsumsinya. Dengan adanya promosi produsen (produk/jasa) atau distributor mengharapkan kenaikannya angka penjualan. Promosi merupakan suatu aktivitas komunikasi dari pemilik produk atau jasa yang ditujukan kepada masyarakat, dengan tujuan supaya produk atau jasa, merek dan nama perusahaan dapat dikenal masyarakat sekaligus mempengaruhi masyarakat supaya mau membeli serta menggunakan produk atau jasa perusahaan. Promosi yaitu kegiatan dari pemasaran maupun penjualan dalam rangka untuk meninformasikan dan mendorong permintaan konsumen terhadap produk atau jasa dari suatu perusahaan dengan mempengaruhi konsumen supaya membeli produk atau jasa yang dijual oleh perusahaan. Promosi merupakan cara yang dilakukan oleh pemasar untuk meninformasikan dan mempengaruhi para konsumen atau masyarakat sehingga dapat tertarik untuk membeli serta menggunakan produk ataupun jasa yang dipasarkannya.

Tujuan promosi di antaranya adalah:

1) Menyebarkan informasi produk kepada target pasar potensial

2) Untuk mendapatkan kenaikan penjualan dan profit/laba

3) Untuk mendapatkan pelanggan baru dan menjaga kesetiaan pelanggan

4) Untuk menjaga kestabilan penjualan ketika terjadi lesu pasar

5) Membedakan serta mengunggulkan produk dibanding produk pesaing

6) Membentuk citra produk di mata konsumen sesuai dengan yang diinginkan.

7) Mengubah tingkah laku dan pendapat konsumen

\subsection{Strategi Sosialisasi Dan Promosi}

Produsen sebuah produk baik barang atau jasa, membutuhkan strategi promosi yang tepat untuk mengenalkan produknya kepada konsumen. Strategi promosi produk sangat dibutuhkan. Karena tanpa adanya kegiatan promosi, sebuah produk tidak akan dikenal masyarakat. Makanya para pengusaha saling berlomba menggunakan berbagai strategi untuk mempromosikan produk mereka, guna memperoleh perhatian dari masyarakat.

Kegiatan promosi produk, tidak selamanya membutuhkan biaya yang cukup besar. Bagi Anda yang memiliki dana terbatas sekalipun, kegiatan promosi produk juga dapat dilakukan. Yang terpenting adalah kreatifitas produsen untuk menyusun strategi promosi dengan meminimalisir dana. Namun tetap perlu diingat, promosi dengan dana yang optimal, tentu akan menghasilkan respon pasar yang lebih optimal.

\subsection{Langkah - Langkah Penetapan Media}

Langkah-langkah dalam merancang pengembangan media promosi kesehatan adalah sebagai berikut:

1) Menetapkan tujuan: Tujuan harus realistis, jelas, dan dapat diukur (apa yang diukur, siapa sasaran yang akan diukur, seberapa banyak perubahan akan diukur, berapa lama dan dimana pengukuran dilakukan). Penetapan tujuan merupakan dasar untuk merancang media promosi dan merancang evaluasi. Menetapkan segmentasi sasaran

2) Segmentasi sasaran adalah suatu kegiatan memilih kelompok sasaran yang tepat dan dianggap sangat menentukan keberhasilan promosi kesehatan. Tujuannya antara lain memberikan pelayanan yang sebaikbaiknya, memberikan kepuasan pada masing-masing segmen, menentukan ketersediaan jumlah dan jangkauan produk, serta menghitung jenis dan penempatan media.

3) Memposisikan pesan (positioning): Memposisikan pesan adalah proses atau upaya menempatkan suatu prosuk perusahaan, individu atau apa saja ke dalam alam pikiran sasaran atau konsumennya. Positioning membentuk citra.

4) Menentukan strategi positioning: Identifikasi para pesaing, termasuk persepsi konsumen, menentukan posisi pesaing, menganalisis preferensi khalayak sasaran, menetukan posisi merek produk sendiri, serta mengikuti perkembangan posisi.

5) Memilih media promosi: Pemilihan media didasarkan pada selera khalayak sasaran. Media yang dipilih harus memberikan dampak yang luas. Setiap media akan memberikan peranan yang berbeda. 


\section{Syafiatun Siregar - Nahesson Panjaitan}

Penggunaan beberapa media secara serempak dan terpadu akan meningkatkan cakupan, frekuensi, dan efektivitas pesan.

6) Media cetak: Media cetak yaitu suatu media statis dan mengutamakan pesanpesan visual. Pada umumnya terdiri atas gambaran sejumlah kata, gambar, atau foto dalam tata warna. Contohnya poster, leaflet, brosur, majalah, surat kabar, lembar balik, stiker, dan pamflet. Fungsi utamanya adalah memberi informasi dan menghibur. Kelebihan yang dimiliki media cetak antara lain tahan lama, mencakup banyak orang, biaya tidak terlalu tinggi, tidak perlu energi listrik, dapat dibawa, mempermudah pemahaman, dan meningkatkan gairah belajar. Kelemahannya tidak dapat menstimulasi efek suara dan efek gerak serta mudah terlipat.

7) Media elektronik: yaitu suatu media bergerak, dinamis, dapat dilihat, didengar, dan dalam menyampaikan pesannya melalui alat bantu elektronika. Contohnya televisi, radio, film, kaset, CD, VCD, DVD, slide show, CD interaktif, dan lain-lain. Kelebihan media elektronik antara lain sudah dikenal masyarakat, melibatkan semua pancaindra, lebih mudah dipahami, lebih menarik karena ada suara dan gambar, adanya tatap muka, penyajian dapat dikendalikan, janagkauan relatif lebih besar/luas, serta dapat diulang-ulang jika digunakan sebagai alat diskusi. Kelemahannya yaitu biaya lebih tinggi, sedikit rumit, memerlukan energi listrik, diperlukan alat canggih dalam proses produksi, perlu persiapan matang, peralatan yang selalu berkembang dan berubah, perlu keterampilan penyimpanan, dan perlu keterampilan dalam pengoprasian.

8) Media luar ruang: Media luar ruang yaitu suatu media yang penyampaian pesannya di luar ruang secara umum melalui media cetak dan elektronik secara statis. Contohnya papan reklame, spanduk, pameran, banner, TV layar lebar, dan lainlain. Kelebihan media luar ruang diantaranya sebagai informasi umum dan hiburan, melibatkan semua pancaindra, lebih menarik karena ada suara dan gambar, adanya tatap muka, penyajian dapat dikendalikan, jangkauan relatif lebih luas. Kelemahannya yaitu biaya lebih tinggi, sedikit rumit, ada yang memerlukan listrik atau alat canggih, perlu kesiapan yang matang, peralatan yang selalu berkembang dan berubah, perlu keterampilan penyimpanan.

\section{Hasil dan Pembahasan}

Pendidikan tinggi pada hakikatnya adalah suatu kegiatan sarana belajar dan mengajar yang dilakukan oleh suatu institusi terhadap mahasiswa, baik yang terstruktur maupun yang tidak. Dengan harapan bahwa dengan adanya proses pembelajaran tersebut, maka mahasiswa dapat memperoleh pengetahuan tentang kesehatan yang lebih baik. Pengetahuan tersebut pada akhirnya diharapkan dapat berpengaruh terhadap perilaku dan pengetahuan. Sebagai salah satu program studi yang baru terbentuk, Program Studi S1 Teknik Sipil Unimed perlu melakukan sosialisasi dan promosi agar lebih dikenal di masyarakat luas terutama calon mahasiswa.

Kegiatan promosi yang dilakukan sebelum penerimaan mahasiswa baru. Kegiatan dilakukan dengan berbagai metode sosialisasi dan promosi, antara lain dengan menyebarkan brosur ke sekolah-sekolah, melalui media massa, melalui media social maupun secara oral melalui alumni jurusan Pendidikan Teknik Bangunan. Media promosi yang dilakukan adalah semua sarana atau upaya menampilkan pesan atau informasi yang ingin disampaikan oleh komunikator, baik melalui media cetak, elektronika, dan media luar ruang, sehingga pengetahuan sasaran dapat meningkat dan akhirnya dapat mengubah perilaku ke arah positif terhadap kesehatan (Soekidjo, 2005).

\subsection{Promosi Melalui Media Sosial}

Promosi yang dilakukan oleh program studi S1 Teknik Sipil adalah dengan melakukan promosi melalui media. Promosi di media adalah cara yang paling klasik, sudah ada dan sudah dipakai sejak zaman dulu. Promosi di media sampai saat ini masih cukup unggul karena jangkauannya bisa sampai ke pelosok. Sebab sistem distribusi media massa memang sudah terbangun sekian waktu. Selain itu, media massa juga yang paling mudah diakses oleh semua kalangan. Misalnya orang tua calon mahasiswa bisa mengetahui informasi perguruan tinggi dari koran; calon mahasiswa bisa mengetahui info pendaftaran dari iklan televisi yang tidak sengaja ditonton; maupun kerabat bisa tahu info yang sama dari iklan radio yang didengar saat tengah terjebak macet.

Media lain yang digunakan dalam kegiatan ini adalah berupa pembuatan brosur dan menyebarkannya di berbagai sekolah di seputaran Kota Medan. Penyebaran brosur juga 


\section{Promosi Dan Pemetaan Mahasiswa Baru Program Studi (S1) Teknik Sipil Jurusan Pendidikan Teknik Bangunan Fakultas Teknik Unimed}

dilakukan dengan menggunakan jasa para alumni. Brosur diberikan kepada alumni Jurusan Pendidikan Teknik Bangunan untuk dibagikan ke daerah-daerah asal para alumni ataupun tempat alumni berkerja. Sehingga para calon mahasiswa baru mendapatkan informasi tentang keberadaan program studi ini, mengingat program studi ini adalah program studi baru yang ada di Jurusan Pendidikan Teknik Bangunan Unimed. Selain melalui media massa, dan brosur, promosi ini juga dilakukan melalui media sosial yang sedang tren saat ini seperti Facebook dengan laman yang dapat di akses https://www.facebook.com/profile.php?id=10 0014754993810.

Mahasiswa yang aktif dan alumni diajak bergabung dalam grup Teknik Sipil Unimed dimana admin grupnya adalah ketua Program Studi S1 Teknik Sipil Unimed serta beberapa dosen lainnya. Melalui media ini, program studi lebih cepat dikenal dan diketahui masyarakat terutama calon mahasiswa baru. Hasilnya bahwa terdapat beberapa mahasiswa yang mengetahui program studi ini melalui media sosial yang dimaksud.

\subsection{Penyebaran Brosur}

Sarana sosialisasi dan promosi yang dilakukan Program Studi Teknik Sipil S1 FT Unimed adalah melalui penyebaran brosur. Penyebaran brosur dilakukan sebelum ujian/selesksi masuk di perguruan tinggi, baik di jalur SNMPTN, SBMPTN dan Mandiri. Brosur disebarkan melalui kunjungan ke persekolahan yang ada di Sumatera Utara yaitu ke Kabupaten Lubuk Pakam, Binjai, Tobasa dan lain-lain. Selain itu brosur juga disebarkan melalui alumni yang datang berkunjung ke jurusan. Ketua program studi menitipkan beberapa lembar brosur agar disebarkan alumni kepada anggota keluarganya, anggota masyarakat di daerahnya maupun menginformasikan melalui media lainnya. Selain itu brosur juga dikirimkan ke beberapa sekolah yang ada di Sumatera Utara.

Penyebaran brosur juga dilakukan dengan akses komunikasi yang ada sekarang ini. Kemudahaan akses komunikasi yang ada saat ini membuat penyebaran brosur sangat cepat dan mudah dilakukan. Ketua program studi melakukan komunikasi dengan para alumni Pendidikan Teknik Bangunan Fakultas Teknik Unimed yaitu dengan mengirimkan brosur melalui media sosial Whatsapp dan Facebook. Selanjutnya para alumni ikut berpartisipasi menyebarkan brosur melalui media tersebut ke berbagai kalangan.

\subsection{Pemetaan Mahasiswa Baru}

Sosialisasi dan promosi yang dilakukan selama kurang lebih 3 bulan dimulai dari awal tahun 2017 telah berjalan dengan baik. Secara spesifik hasil sosialisasi dan promosi ini dapat dilihat dari jumlah peminat yang mendaftar di SNMPTN, SBMPTN maupun jalur mandiri. Walaupun program studi ini merupakan program studi yang baru terbentuk dan baru dapat menerima mahasiswa tahun ajaran ganjil 2017/2018, tetapi antusiasme mahasiswa baru cukup tinggi. Program studi Teknik Sipil pada dasarnya hampir semua ada di universitas swasta maupun negeri di Sumatera Utara. Yang menjadikan Program studi Teknik Sipil ini diminati karena berada di bawah Unimed yang merupakan salah satu Universitas Negeri dari 4 Universitas negeri yang ada di Sumatera Utara (USU, UINSU dan Politeknik Negeri Medan).

Tabel 1. Hasil Jalur Seleksi Prodi Teknik Sipil S1 PTB FT Unimed

\begin{tabular}{|c|c|c|c|c|}
\hline \multirow[b]{2}{*}{ No } & \multirow[b]{2}{*}{$\begin{array}{l}\text { Jalur } \\
\text { seleksi }\end{array}$} & \multicolumn{3}{|c|}{ Jumlah (orang) } \\
\hline & & Peminat & Diterima & $\begin{array}{c}\text { Mendaftar } \\
\text { ulang }\end{array}$ \\
\hline 1 & SNMPTN & 406 & 27 & 24 \\
\hline 2 & SBMPTN & 1.317 & 39 & 34 \\
\hline 3 & Mandiri & 708 & 41 & 28 \\
\hline & Jumlah & 1.431 & 108 & 86 \\
\hline
\end{tabular}

Dari Tabel 1 diatas terlihat bahwa banyaknya peminat (calon mahasiswa) yang ingin masuk ke prodi Teknik Sipil. Kondisi diatas menunjukkan bahwa Teknik Sipil masih merupakan program studi yang favorit, mengingat bahwa prodi ini baru menerima mahasiswa pada semester ini. Peminat cukup tinggi pada jalur SBMPTN yaitu sebesar 1317 orang sedangkan yang diterima hanya 39 orang. Jalur mandiri adalah jalur seleksi yang dilakukan oleh Unimed tanpa kerjasama dengan perguruan tinggi lain. Tabel diatas juga menunjukkan tingginya calon mahasiswa yang tidak mendaftar ulang terutama di jalur mandiri (22 orang). Hal ini kemungkinan dikarenakan adanya dana penyertaan yang disyaratkan oleh institusi yaitu sebesar Rp. 10 juta, apalagi dana tersebut tidak dapat dicicil. Atau kemungkinan lain adalah diterimanya calon mahasiswa tersebut di institusi lain selain unimed mengingat banyanya institusi yang melaksanakan seleksi pada waktu yang bersamaan. 
Tabel 2. Tingkat Persaingan Masuk Teknik Sipil S1 PTB Unimed

\begin{tabular}{|c|c|c|c|c|}
\hline \multirow[b]{2}{*}{ No } & \multirow{2}{*}{$\begin{array}{l}\text { Jalur } \\
\text { seleksi }\end{array}$} & \multicolumn{3}{|c|}{ Jumlah (orang) } \\
\hline & & Peminat & Diterima & $\begin{array}{c}\text { Tingkat } \\
\text { persaingan }\end{array}$ \\
\hline 1 & SNMPTN & 406 & 24 & $1: 20$ \\
\hline 2 & SBMPTN & 1.317 & 34 & $1: 39$ \\
\hline 3 & Mandiri & 708 & 28 & $1: 25$ \\
\hline & $\begin{array}{l}\text { nlah/Rata- } \\
\text { rata }\end{array}$ & 1.431 & 86 & $1: 28$ \\
\hline
\end{tabular}

Tingkat persaingan antara jumlah peminat dan yang diterima pada Prodi Teknik Sipil S1 cukup tinggi (Tabel 2). Hal ini terlihat pada jalur SBMPTN, dimana tingkat persaingan adalah 1:39 yang artinya dari 39 peminta hanya satu orang yang dapat diterima. Demikian juga untuk jalur SBMPTN dan SNMPTN yang mempunyai tingkat persaingan yang tinggi. Secara keseluruhan menyatakan bahwa prodi Teknik Sipil S1 mampu bersaing dengan perguruan tinggi negeri lainnya di Kota Medan. Tingginya tingkat persaingan masuk Unimed dapat disimpulkan bahwa mahasiwa S1 Teknik Sipil adalah mahasiswa yang melalui saringan yang cukup ketat. Diharapkan input yang tersaring akan meningkatkan kualitas mahasiswa dan pada akhirnya meningkatkan kualitas lulusan dan daya saing di pasar kerja Teknik Sipil.

Seperti yang disajikan pada Tabel 1 dan Tabel 2 yaitu dimana mahasiswa yang mendaftar ulang sebesar 86 orang. Mahasiswa yang berhasil lulus masuk Program studi S1 Teknik Sipil bukan berasal dari wilayah Kota Medan saja, tetapi sudah mencakup wilayah Pulau Sumatera. Hasil analisis yang dilakukan terhadap mahasiswa baru Teknik Sipil S1 didapat hasil daerah asal dari mahasiswa tersebut serta sumber informasi kenberadaan dari prodi ini. Adapun rincian daerah asal mahasiswa dan sumber informasi keberadaan Teknik Sipil dapat dilihat pada Tabel 3. berikut:

Tabel 3. Daerah Asal Mahasiswa Teknik Sipil S1 PTB Unimed

\begin{tabular}{llcr}
\hline No & Daerah Asal & Jumlah & $\begin{array}{c}\text { Persentase } \\
(\mathbf{\%})\end{array}$ \\
\hline 1 & Kota Medan & 30 & 34,88 \\
\hline 2 & $\begin{array}{l}\text { Sumatera } \\
\text { Utara }\end{array}$ & 43 & 50,00 \\
\hline 3 & Sumatera & 9 & 10,47 \\
\hline 4 & Luar Sumatera & 4 & 4,65 \\
\hline Jumlah & 86 & 100,00 \\
\hline Sumber: Analisis Data, 2017 & &
\end{tabular}

Dari Tabel 3 dapat dilihat asal dari mahasiswa baru Teknik Sipil PTB Unimed. Secara umum mahasiswa baru berasal dari Kota Medan yaitu 34,88 \% yang berasal dari berbagai Sekolah Menengah Umum (SMA) dan SMK (Sekolah Menengah Kejuruan) baik Negeri dan Swasta dari Kota Medan. Mahasiswa yang berasal dari Sumatera Utara cukup bervariasi, yaitu dari Toba Samosir, Binjai, Dairi, Kisaran, Nias dan lain-lain. Sedangkan dari Pulau Sumatera yaitu berasal dari Aceh, Padang, Jambi, Palembang dan Riau. Dari luar Pulau Sumatera terdata ada 4 orang (jawa), hal ini menunjukkan bahwa Teknik Sipil USU dapat bersaing secara regional. Dari hasil survey menyatakan bahwa umumnya dari SMA jurusan IPA yang artinya sesuai dengan bidang yang diambilnya. Sedangkan untuk SMK masih bervariasi, ada yang dari SMK Teknik Bangunan, Mesin, Otomotif, Komputer dan jaringan dan lain-lain.

Tabel 4. Sumber Informasi Keberadaan Teknik Sipil PTB Unimed

\begin{tabular}{llc}
\hline No & Sumber informasi & Jumlah \\
\hline 1 & Sekolah & 12 \\
\hline 2 & Web & 36 \\
\hline 3 & Brosur & 5 \\
\hline 4 & Alumni & 17 \\
\hline 5 & Bimbingan Belajar & 12 \\
\hline 6 & Lainnya & 4 \\
\hline Jumlah & 86 \\
\hline \multicolumn{2}{l}{ Sumber: Analisis Data, 2017 }
\end{tabular}

Sumber informasi dari keberadaan Teknik Sipil S1 PTB Unimed yang didata dari mahasiswa dapat dilihat pada Tabel 4. Dari sajian tabel tersebut terlihat bahwa jaringan internet (Web) berperan cukup besar (36 orang). Ini menyatakan bahwa peranan jaringan media komunikasi melalui web adalah sarana yang paling mudah diakses jika melakukan promosi. Hal ini senada dengan kemudahan alat komunikasi yang ada pada saat ini. Sumber internet sudah dapat menjangkau hampir diseluruh pelosok Sumatera Utara, sehingga prodi S1 Teknik Sipil dapat diketahui masyarakat keberadaannya.

Alumni juga berperan aktif sebagai mediator dalam promosi ini (17 orang). Alumni yang dimaksud bukan hanya alumni jurusan Pendidikan Teknik Bangunan, tetapi mencakup alumni Fakultas Teknik, maupun alumni Fakultas lain yang ada di lingkungan Unimed. Oleh karena itu peran dan wadah alumni diharapkan dapat meningkatkan kualitas dan kuantitas mahasiswa. Selain itu sekolah dan 


\section{Promosi Dan Pemetaan Mahasiswa Baru Program Studi (S1) Teknik Sipil Jurusan Pendidikan Teknik Bangunan Fakultas Teknik Unimed}

bimbingan belajar adalah tempat yang baik juga untuk sarana informasi.

Tabel 5. Pemilihan Minat Program Studi Teknik Sipil S1 PTB Unimed

\begin{tabular}{|c|c|c|c|}
\hline No & Pilihan & $\begin{array}{l}\text { Jumlah } \\
\text { (orang) }\end{array}$ & $\begin{array}{c}\text { Persentase } \\
(\%)\end{array}$ \\
\hline 1 & Pilihan 1 & 48 & 55,82 \\
\hline 2 & Pilihan 2 & 26 & 30,23 \\
\hline 3 & Pilihan 3 & 12 & 13,95 \\
\hline & Total & 86 & 100,00 \\
\hline
\end{tabular}

Tabel 5. menyajikan data minat dari mahasiswa baru Teknik Sipil S1 PTB Unimed. Hasilnya bahwa 55,82 \% menyatakan bahwa Prodi Teknik Sipil S1 PTB Unimed adalah pilihan pertama dari tiga pilhan program studi yang ditawarkan. Selanjutnya pilihan kedua, sebesar 26 orang $(30,23 \%)$ dan diiukti oleh pilihan ketiga sebesar 13,95 \%. Dari tabel diatas menunjukkan bahwa minat untuk memasuki Program Studi Teknik Sipil S1 PTB Unimed sangat tinggi ini dilihat dari pilihan para mahasiswa baru dimana S1 Teknik Sipil Unimed adalah pilihan pertama mereka dalam memasuki perguruan tinggi.

\section{Simpulan dan Saran}

\subsection{Simpulan}

Berdasarkan analisis, hasil dan pembahasan yang dijabarkan di bab III maka didapat kesimpulan dari penelitian Sosialisasi Dan Promosi Program studi Teknik Sipil S1 Jurusan Pendidikan Teknik Bangunan Unimed adalah sebagai berikut:

1) Sosialisasi dan Promosi yang dilakukan dengan menggunakan media sosial dan penyebaran brosur

2) Jumlah mahasiswa baru yang terdaptar pada program studi Teknik Sipil S 1 berjumlah 86 orang dari jumlah peminat sebanyak 1431 orang

3) Tingkat persaingan cukup tinggi yaitu rata-rata $1: 28$

4) Daerah asal mahasiwa sudah secara regional mencakup pulau Sumatera Dan Pulau Jawa

5) Sumber informasi keberadaan Teknik Sipil S1 PTB FT Unimed diketahui melalui sumber informasi yang berbeda seperti dari sekolah, Web, jejaring social, alumni dan lain-lain

6) Umumnya Program studi S1 Teknik Sipil merupakan pilihan pertama dari mahasiswa baru

\subsection{Saran}

Program studi S1 Teknik Sipil Jurusan Pendidikan Teknik Bangunan FTUnimed adalah program studi yang baru terbentuk tahun 2017. Program studi ini baru menerima mahasiswa pada tahun ajaran semester ganjil 2017/2018. Minat calon mahasiswa baru untuk memasuki program studi ini sangat tinggi. Khusus untuk jalur mandiri jumlah peminat dan yang lulus sebenarnya sangat banyak. Terdapat 13 orang peminat yang mengundurkan diri atau tidak mendaftarkan ulang. Hal ini kemungkinan disebabkan adanya aturan untuk membayar uang penyertaan yang cukup tinggi dan harus dibayarkan tunai. Oleh karena itu perlu kiranya institusi lebih bijak menghadapi ini. Agar porsi jumlah mahasiswa baru sesuai dengan yang diharapkan.

\section{Daftar Pustaka}

Abdurrahman, Mulijono. 2009. Pendidikan Bagi Anak Berkesulitan Belajar. Jakarta. Rineka Cipta. h. 253

Arends, R. 2001. Learning to Teach. New York: Mc graw Hill Companies, Inc

Desri. Yeri Fitriani, Cesaria. Anna, Estetikasari, Dewi. 2017. Pengaruh Penerapan Model Pembelajaran Langsung dengan Teknik Spotlight Terhadap Pemahaman Konsep Matematis Siswa Kelas VIII SMPN 25 Padang.

http:/ /jim.stkip-

pgrisumbar.ac.id/jurnal/download/47 55 (diaekse tanggal 8 Agustus 2017)

Hake. 1999. Analyzing Change/Gain Scores. 24245 Hatteras Street Dept, of Physics, Indiana University. USA. Woodland Hills, CA, 91367

Kardi dan Nur. 2000. Pengajaran Langsung. Surabaya: Unesa - University Press. h.5 Suastra, IW. 2009. Pembelajaran Sains Terkini. Undiksha: Singaraja Sugiyono. 2010. Metode Penelitian Administratif. Bandung: Alfabeta.

Enny Keristiana Sinaga - Syafiatun Siregar Asri Lubis Educational Building, Vol. 3. No.2 Desember 201726

Sugiyono. 2013. Metode Penelitian Pendidikan Pendekatan Kuantitatif, Kualitatif, dan R\&D. Bandung: Alfabeta.

Surajiyo. 2008. Filsafat Ilmu. Jakarta: Bumi 